\title{
An international forestry organization: Do we need one? ${ }^{1}$
}

\author{
by Ralph W. Roberts ${ }^{2}$ and John Roper ${ }^{3}$
}

\section{Introduction}

Forests cover approximately $26 \%$ of the world's land surface. They are important economically for the many wood and non-wood products they provide. Lumber, panels, pulp and paper are important commodities of trade. Global production of wood products is valued at \$US 400 billion per year, the equivalent of $2 \%$ of the world's GDP. Firewood and charcoal are still major sources of energy in many countries. Nonwood forest products are particularly important in developing countries as food and traditional medicines. Forests are also important for their environmental services - for their biodiversity, sequestration and storage of atmospheric carbon, and their role in soil conservation and fresh water production. They are also important from a socio-cultural perspective-they form part of the spiritual heritage of indigenous peoples, enter into our customs and folklore, and for Canadian, are part of our national identity.

Despite their importance, there exist many serious challenges to the long-term management and rational utilization of forests. The absence of sustainable forest management practices, tropical deforestation, desertification, forest degradation, and global climate change all threaten the resource. Progress is impeded by weak national institutions, lack of political will, the absence of global policies and strategies, restrictive trade policies and practices, the lack of an International Forest Convention, inappropriate fiscal and development policies, lack of timely resource and trade information, and an undervaluation of natural forests. The challenges facing forests and forestry are further frustrated by the lack of an effective international organization to provide global leadership for the sector.

\section{Current Institutional Players}

There are a plethora of institutions in the world that are responsible for forests and their management or are involved in some way in forest-related issues. National governments, provincial or state governments, and communities have the primary responsibility for forests that fall within their jurisdictions. They are usually under-staffed, under-budgeted, and lack the political support necessary to obtain the decisions needed to ensure the long-term viability of the resource. While they have the legal mandate over forests, national-level institutions have limited capacity and authority to deal with global issues.

Operating internationally, there are a number of United Nations agencies involved in forest-related issues. The UN Food and Agriculture Organization (FAO) acts by default as the world leader in forestry despite the fact that FAO's main priorities are related to its food production mandate. For decades, FAO has only dedicated about $4.5 \%$ of its budget to forests-down

\footnotetext{
${ }^{1}$ Presentation to the Canadian Institute of Forestry, Whistler, British Columbia, August 16, 2001.

${ }^{2}$ Senior Adviser, Forestry and Conservation, Canadian International Development Agency.

${ }^{3}$ Consultant in International Forestry.
}

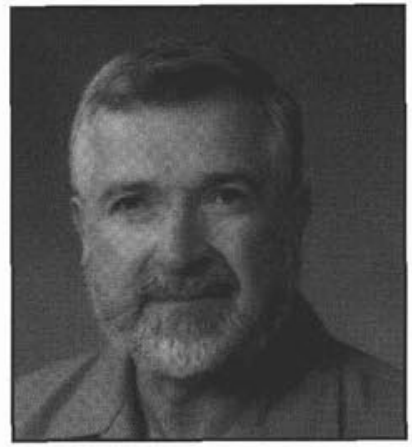

Ralph W. Roberts

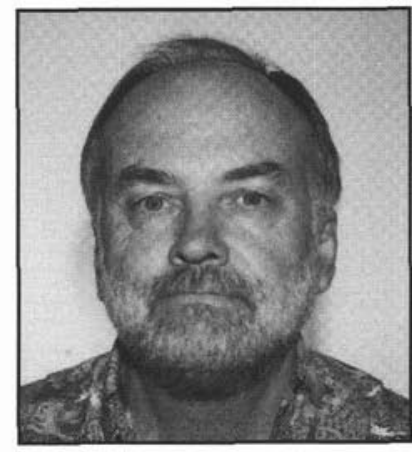

John Roper from nearly $10 \%$ in the 1950 s. In 1995 , the UN Commission on Sustainable Development created the Intergovernmental Panel on Forests (IPF) to follow up on the global forest policy dialogue of the 1992 UNCED conference in Rio de Janeiro. The IPF examined the implementation of UNCED agreements; international cooperation; scientific research, forest assessment and the development of criteria and indicators; trade and environment, and the roles of international organizations and multilateral institutions and instruments. With much of the work still unfinished, the IPF was succeeded by the Intergovernmental Forum on Forests (IFF), which in turn has been replaced by the United National Forum on Forests (UNFF).

Other UN agencies involved in forestry include the World Food Programme (WFP), which has been traditionally the largest donor to the sector, mainly through its reforestation projects in Developing Countries. However, WFP's contribution to forestry as a percentage of its total budget has been declining. Forestry accounted for $6 \%$ of WFP's budget in 1991 but had fallen to only $1.3 \%$ by 1999 . The International Tropical Timber Organization (ITTO) focuses on the management, production, and trade of tropical forests and tropical forest products. It does not have a mandate to cover temperate and boreal forests. Until recently, the United Nations Development Programme (UNDP) played an important role in the funding of forest-related development projects, particularly in collaboration with FAO; however, UNDP has withdrawn from forestry programming to focus on the social aspects of development. Other UN players include the UN Educational, Scientific, and Cultural Organization, the UN Industrial Development Organization, and the International Labour Organization.

International financial institutions (IFI) are active in the sector through their funding to development programmes. The $1990 \mathrm{~s}$ were characterized by policy reviews, particularly at the World Bank, on the nature of their role in forestry. Continuing commitments to the sector are uncertain with current disbursement running at about $1 \%$ of the value of the IFI's total loans. Most bilateral aid agencies, like the Canadian International Development Agency (CIDA), are involved in forestry. Their financial support has been steadily declining during the last decade. In the case of CIDA, current disbursements are approximate- 
ly $\$ 40$ million annually or $1.6 \%$ of Canada's official development assistance budget, down from $3.5 \%$ in 1989 .

Other players include international research organizations like the International Union of Forest Research Organizations (IUFRO) or institutions like the International Centre for Research in Agroforestry (ICRAF) and the Centre for International Forest Research (CIFOR), and non-governmental organizations like the International Union for the Conservation of Nature (IUCN), the Rainforest Action Network (RAN), or the World Wildlife Fund (WWF). The use of forests and forest products and the management of forest lands are subject to numerous international agreements, including the Framework Convention on Climate Change, the Convention on Biological Diversity, and the Convention to Combat Desertification to name a few.

The forest industries and investment houses have been involved in the management of natural forests and in creation of forest plantations. They are becoming increasingly influential on how forests and forest lands are managed. However, they have played only a marginal role to date in the high-level policy dialogue at the UNFF.

Clearly, there are many institutions and legal instruments concerned with forests. Overlaps and gaps exist in their mandates and none of them are investing the resources needed to meet the challenges of the $21^{\text {st }}$ century. No one institution has a comprehensive, all encompassing terms of reference that focuses on all of the world's forest ecosystems, all aspects of sustainable forest management, and provides the much needed leadership for the sector.

\section{Institutional Problems}

As would be expected, numerous institutional problems exist that frustrate attempts to make meaningful progress to address global issues. Although there is a multitude of institutional players, there is no single, high-level body that is dedicated to international forest issues and there is no permanent, institutional leadership. There are overlaps and gaps in institutional mandates that result in slow, incomplete, inefficient approaches to resolving issues. The existing institutions have very limited capacities to develop global strategies and policies, monitor environmental services of forests, monitor and analyze biophysical and socioeconomic information, and give support to education, training, and research.

For many of the institutions, forestry is not a priority. It is overshadowed by their other priorities even though they have some responsibility for forests. For example, FAO's preoccupation is with food and fish, not forests. The IFI's are concerned for overall economic development, not just forests, and the Global Environment Facility (GEF) focuses on the environment, not just forest ecosystems. Without this sense of priority, forestry has suffered from inadequate budgets and under-staffing. Global budgets for forestry investments are declining in spite of worsening conditions (e.g., continuing loss of biodiversity and advancing deforestation) and the rising public expectations that concrete steps will be taken towards sustainable forest management.

There is limited participation by all actors in governance in the forest sector. Participation in global fora is still dominated by governmental and multilateral organizations. NGOs, aboriginal groups, forest industries, and investment houses are being routinely "consulted" but they have limited involvement in actual decision-making. Despite recent advances in technology, international communications in forestry remain weak, both regionally and on a global basis.

After two decades of sincere attempts to improve the situation, overall coordination of development assistance program planning, implementation, and evaluation remains weak. It is still dependent on the willingness of individual national governments and specific donors to collaborate on an ad hoc basis, resulting in inefficient use of scarce resources.

There is still no International Forest Convention-a legally binding, common understanding and agreement on sustainable forest management concepts. As a consequence, there is no legal framework for monitoring and compliance of forestry practices and forestry does not have a legal instrument of equivalent stature to other conventions.

\section{A New Institution is Needed}

For there to be meaningful progress towards resolving the important global forest issues, there must be institutional reform. Forestry needs one institution that acts as its focal point and that provides leadership in global affairs. The health sector has the World Health Organization, agriculture sector has the FAO, trade has the World Trade Organization, but forestry has no such organization.

A new international forestry organization would:

- have sustainable forest management as its principal mandate with priorities, budgets and strategies primarily related to forests, their utilization and conservation, and the people who depend on them;

- have high-level political support including the participation of a Council of Ministers responsible for forests in its governance structure;

- have broad-based stakeholder participation that includes all stakeholders - governments, NGOs, forest industries, and investment houses;

- be an operational entity with a clear mandate and adequate human and financial resources;

- be an institutional "peer" and equal to the lead organizations of other sectors on the world stage;

- include nations with all types of forests, from boreal to tropical, from forest-rich to forest-poor.

It would have the mandate for and the capacity to:

- identify international forest issues and be able to set priorities to act on them;

- develop global strategies and policies;

- instruct, advise, and recommend on a wide range of global forest issues;

- monitor, evaluate, provide feedback and exchange information on forest issues;

- support education, training, and research;

- promote and support the adoption of an International Forest Convention;

- improve the coordination of development assistance programming in forestry ;

- attract more ODA funding for forestry programming in developing countries.

What are the options available for creating a new organization? One option would be to create a new organization outside the UN system with a hybrid governance structure that embraces both governmental and non-governmental members similar to IUCN. This would be an innovative option that could meet all 
the essential requirements but would be handicapped by the general reluctance to commit resources to create new institutions, particularly independent ones outside the established structures. Another option would be to reform FAO's mandate to give forestry greater importance. This would be very close to maintaining the status quo since FAO's priorities are in agriculture and always will be, hence, a high risk of business as usual. Furthermore, it would be unlikely that FAO would agree to reform its governance structure. FAO's governing council is composed of Agriculture Ministers with little private sector and NGO participation. It would be as difficult to establish forestry priorities and capture new resources for forestry as it is today.

A third option would be to create a new and independent forest organization within the UN system - create a UN Global Alliance For Forests (GLOBALFOR) that would report directly to the UN General Assembly like the FAO or the World Health Organization (WHO) do now. This option would require reforming the mandates of the other UN agencies currently involved in forestry.
Through consolidation, GLOBALFOR would actually lead to a reduction in the number of international forest-related institutions. This is a pleasing prospect for all those who resist "the proliferation of new institutions." The ITTO and CIFOR could be brought under one roof along with the forest-related programs of FAO and those of the plethora of other UN agencies and bodies.

Few dispute the value of our forests and the importance that should be given to the move towards sustainable forest management. There exists as well a strong consensus on the need to reform UN organizations, to make them more effective and inclusive. A new and independent world forest organization would advance both of these critically important agendas. Finally, where better to site GLOBALFOR than in Canada, a country rich in forest values and traditions and a leader in the conservation of our global forest heritage.

For more information on international forestry issues, visit the CIDA Forestry Advisors Network (CFAN) website at http://www.rcfa-cfan.org 